\title{
Calcium silicate ameliorates zinc deficiency and toxicity symptoms in barley plants through improvements in nitrogen metabolism and photosynthesis
}

\author{
Valeria Paradisone ${ }^{1} \cdot$ Eloy Navarro-León ${ }^{2}$ - Juan M. Ruiz ${ }^{2} \cdot$ Sergio Esposito $^{1} \cdot$ Begoña Blasco $^{2}$
}

Received: 4 April 2020 / Revised: 19 October 2021 / Accepted: 31 October 2021 / Published online: 8 November 2021

(C) The Author(s) 2021

\begin{abstract}
Zinc $(\mathrm{Zn})$ deficiency causes serious issues to plant growth and development, negatively affecting crops in many world regions. On the other hand, Zn toxicity impairs plant growth, producing physiological alterations, and even cell death. In plants, two of the processes that most determine growth are nitrogen $(\mathrm{N})$ metabolism and photosynthesis. In the last decades, several authors proved that silicon $(\mathrm{Si})$ and calcium $(\mathrm{Ca})$ mitigate the effects of various abiotic and biotic stresses in plants. The objective of this research is to study the effect of $\mathrm{Si}$ application to barley (Hordeum vulgare cv. Nure) plants grown under $\mathrm{Zn}$ deficiency and $\mathrm{Zn}$ toxicity. Hence, barley plants were grown in hydroponics and supplied with a low $\mathrm{Zn}$ dose $\left(0.01 \mu \mathrm{M} \mathrm{ZnSO}_{4}\right)$ and a high $\mathrm{Zn}$ dose $\left(100 \mu \mathrm{M} \mathrm{ZnSO}_{4}\right)$ and were supplied with $\mathrm{CaSiO}_{3}$. Parameters related to $\mathrm{Zn}$ accumulation, $\mathrm{N}$ metabolism, and photosynthesis were measured. $\mathrm{Zn}$ stress affected leaf $\mathrm{Zn}$ concentration and reduced biomass in barley plants. Both $\mathrm{Zn}$ toxicity and deficiency inhibited $\mathrm{N}$ metabolism and enhanced photorespiration, increasing stress symptoms. $\mathrm{CaSiO}_{3}$ mitigated $\mathrm{Zn}$ stress effects, probably regulating $\mathrm{Zn}$ levels in plant cells and enhancing $\mathrm{N}$ metabolism and photosynthesis. We conclude that $\mathrm{CaSiO}_{3}$ could be beneficial to grow barley plants in soils with high or low availability of $\mathrm{Zn}$.
\end{abstract}

Keywords Hordeum vulgare $\cdot \mathrm{N}$ metabolism $\cdot$ Photosynthesis $\cdot$ Silicon $\cdot$ Zn deficiency $\cdot \mathrm{Zn}$ toxicity

$\begin{array}{ll}\text { Abbreviations } \\ \text { AA } & \text { Amino acid } \\ \text { AAT } & \text { Aspartate aminotransferase } \\ \text { Chl } a & \text { Chlorophyll } a \\ \text { Chl } b & \text { Chlorophyll } b \\ \text { GB } & \text { Glycinebetaine } \\ \text { GDH } & \text { Glutamate dehydrogenase } \\ \text { GGAT } & \text { Glutamate: glyoxylate aminotransferase } \\ \text { GO } & \text { Glyoxylate oxidase } \\ \text { GOGAT } & \text { Glutamate synthase } \\ \text { GS } & \text { Glutamine synthetase } \\ \text { NiR } & \text { Nitrite reductase } \\ \text { NR } & \text { Nitrate reductase }\end{array}$

Communicated by G. Klobus.

Eloy Navarro-León

enleon@ugr.es

1 Dipartimento di Biologia, Università di Napoli "Federico II", Complesso Universitario di Monte Sant'Angelo, Via Cinthia, 80126 Napoli, Italy

2 Department of Plant Physiology, Faculty of Sciences, University of Granada, 18071 Granada, Spain
NUE $\quad \mathrm{N}$ use efficiency

NUpE N uptake efficiency

NUtE $\quad \mathrm{N}$ utilization efficiency

\section{Introduction}

Plants require an optimal $\mathrm{Zn}$ supply to grow and to maintain a correct metabolism functioning. Thus, $\mathrm{Zn}$ is an essential micronutrient necessary for carbohydrate metabolism, enzyme activation, structural and functional integrity of membranes, gene expression and regulation, and protein and lipid synthesis (Broadley et al. 2007). Thereby, Zn deficiency represents a serious issue, and it is one of the most widespread micronutrient deficiencies (Kabir et al. 2014). Leaves are the plant organs more affected by $\mathrm{Zn}$ shortage, showing alterations in photosynthesis (Brown and Cakmak 1993). On the other hand, in the last decades, numerous terrestrial and aquatic environments have been contaminated by $\mathrm{Zn}$-rich wastes. Plants accumulate the excess of $\mathrm{Zn}$ in their tissues, which alters physiological processes, inhibiting growth, and even cause cell death (Broadley et al. 2007). 
In plants, two of the processes that most determine growth are $\mathrm{N}$ metabolism and photosynthesis (Erenoglu et al. 2011; Pfannschmidt and Yang 2012). Abiotic stresses, such as Zn imbalances, negatively affect these processes. Thus, stress reduces nitrogen $(\mathrm{N})$ uptake and assimilation, photosynthesis efficiency, and chlorophyll content (Song et al. 2014). Zn is involved in $\mathrm{N}$ metabolism as a catalytic and structural constituent of enzymes (Broadley et al. 2007). Zn plays a role in $\mathrm{N}$ metabolism because it has a positive effect on $\mathrm{N}$ use efficiency (NUE), and subsequently in total reduced $\mathrm{N}$ concentration (Das and Green 2013). N metabolism determines crop productivity because $\mathrm{N}$ along with carbon is the basis of amino acids (AAs) and proteins, which are the main products of $\mathrm{NO}_{3}{ }^{-}$assimilation in leaves (Erenoglu et al. 2011). Another important process is photorespiration because it is necessary to ensure adequate $\mathrm{N}$ levels in plants, provide metabolites, and defends against photo-inhibition (Wingler et al. 2000). On the other hand, some nitrogenous compounds, such as glycinebetaine (GB) and proline (Pro), and protect plants against stress acting as stress-tolerance mechanisms (Ashraf and Foolad 2007).

Many researches proved that $\mathrm{Si}$ application is beneficial for plants suffering stress (Song et al. 2014; Guerriero et al. 2016). Indeed, $\mathrm{Si}$ is regularly used as a fertilizer, in spite of it is not an essential nutrient for plants (Epstein 2009). Si can be applied to plants as calcium $(\mathrm{Ca})$ and magnesium silicates or other minerals. Plants uptake $\mathrm{Si}$ as orthosilicic acid, at $\mathrm{pH}$ below 9, and accumulate up to $10 \%$ of the total dry biomass. Poaceae plants such as barley have an active mechanism for Si uptake (Adrees et al. 2015; Rizwan et al. 2015). He et al. (2013) suggested that the main effects of $\mathrm{Si}$ supply involve the generation of an amorphous silica barrier within the apoplast that defends plant cells against biotic and abiotic stresses. Likewise, Si could mobilize the $\mathrm{Zn}$ stored in roots under micronutrient deprivation (Adrees et al. 2015; Hernández-Apaolaza 2014). Furthermore, Song et al. 2014 observed that $1.5 \mathrm{mM} \mathrm{K}_{2} \mathrm{SiO}_{3}$ alleviated $\mathrm{Zn}$ toxicity $(2 \mathrm{mM})$ through the reduction of $\mathrm{Zn}$ phytoavailability in the growth medium. Furthermore, $\mathrm{Ca}$ is a plant macronutrient that is crucial in cell signaling processes and plays a structural role in cell walls and membranes (White and Broadley 2003). An increase in Ca concentration in the culture medium reduces $\mathrm{Zn}$ uptake and translocation, which could help to reduce $\mathrm{Zn}$ toxicity (Prasad et al. 2016).

Rao et al. (2019), Murillo-Amador et al. (2007), and Anitha et al. (2019) proved that $\mathrm{Ca}$ meta-silicate $\left(\mathrm{CaSiO}_{3}\right)$ can be used as fertilizer and to mitigate plant stress. Indeed, the silicate from $\mathrm{CaSiO}_{3}$ is more bioavailable than silicate from $\mathrm{Ca}_{2} \mathrm{SiO}_{4}$. There are no studies about the effect of $\mathrm{CaSiO}_{3}$ on $\mathrm{Zn}$ imbalances. Thereby, taking into account the potential beneficial effects of $\mathrm{Si}$ and $\mathrm{Ca}$, the hypothesis to test in this study is that $\mathrm{CaSiO}_{3}$ application will improve tolerance to Zn deficiency and toxicity of barley plants. In this study, we focus on the effects on photosynthesis and $\mathrm{N}$ metabolism because of the relevance of these processes in plant growth.

\section{Materials and methods}

\section{Plant material, growth conditions, and treatments}

Barley seeds (Hordeum vulgare, Nure) were germinated on moistened filter paper for 7 days. The seedlings were grown in a growth chamber under the following controlled environmental conditions: day/night temperatures of 28/19 ${ }^{\circ} \mathrm{C}$; Relative humidity $60-80 \%$; $16 / 8 \mathrm{~h}$ light/dark photoperiod at a photosynthetic photon flux density (PPFD) of $350 \mu \mathrm{mol} \mathrm{m}^{-2} \mathrm{~s}^{-1}$ (measured at the top of the seedlings with a 190 SB quantum sensor, LI-COR Inc., Lincoln, Nebraska, USA). The plants were placed in a hydroponic system, under these conditions and after 7 days from germination. The composition of the nutritive solution was: $1 \mathrm{mM} \mathrm{Ca}\left(\mathrm{NO}_{3}\right)_{2}$, $0.1 \mathrm{mM} \mathrm{NH}_{4} \mathrm{H}_{2} \mathrm{PO}_{4}, 0.25 \mathrm{MgSO}_{4}, 0.05 \mathrm{mM} \mathrm{KCl}, 12.5 \mu \mathrm{M}$ $\mathrm{H}_{3} \mathrm{BO}_{3}, 10 \mu \mathrm{M}$ Fe-HEDTA, $0.4 \mu \mathrm{M} \mathrm{MnSO}_{4}, 0.1 \mu \mathrm{M} \mathrm{CuSO}_{4}$, and $0.1 \mu \mathrm{M} \mathrm{MoO}_{3}$. The solution was continuously aerated with electric pumps and was renewed daily, adjusting the $\mathrm{pH}$ to 6 using $\mathrm{HCl}$ and $\mathrm{NaOH}$ as required. Treatments were initiated 7 days after germination and were maintained for 14 days. Plants were supplied with three different $\mathrm{Zn}$ doses: $1 \mu \mathrm{M} \mathrm{ZnSO}{ }_{4}$ as control, $0.01 \mu \mathrm{M} \mathrm{ZnSO} \mathrm{Zn}_{4}$ as deficiency treatment and $100 \mu \mathrm{M}$ of $\mathrm{ZnSO}_{4}$ as toxicity treatment. Besides, barley plants were supplied with $0.25 \mathrm{mM} \mathrm{CaSiO}_{3}$ $(+\mathrm{Si})$ or without $\mathrm{CaSiO}_{3}(-\mathrm{Si})$. Thus, six different treatments were applied: $1 \mu \mathrm{M} \mathrm{ZnSO}_{4}, 1 \mu \mathrm{M} \mathrm{ZnSO} \mathrm{Zn}_{4}+0.25 \mathrm{mM}$ $\mathrm{CaSiO}_{3}, 0.01 \mu \mathrm{M} \mathrm{ZnSO}, 0.01 \mu \mathrm{M} \mathrm{ZnSO} \mathrm{ZnS}_{4}+0.25 \mathrm{mM}$ $\mathrm{CaSiO}_{3}, 100 \mu \mathrm{M} \mathrm{ZnSO} \mathrm{Zn}_{4}+0.25 \mathrm{mM} \mathrm{CaSiO}_{3}, 100 \mu \mathrm{M}$ $\mathrm{ZnSO}_{4}+0.25 \mathrm{mM} \mathrm{CaSiO}_{3}$. The use of $\mathrm{CaSiO}_{3}$ and the utilized doses were selected based on a previous experiment growing barley plants with several $\mathrm{ZnSO}_{4}$ and $\mathrm{CaSiO}_{3}$ doses (data not shown) and in other studies (Murillo-Amador et al. 2007; Song and Jeong 2014; Anitha et al. 2019). The experimental design consisted of two factors, $\mathrm{Zn}$ dose applied and $0.25 \mathrm{mM} \mathrm{CaSiO}_{3}$ application. Treatments were added in nutrient solutions at the beginning of hydroponic growth. The experimental design consisted of a randomized complete block with six treatments, arranged in individual benches with twenty plants per treatment and three replications each.

\section{Plant sampling}

Plant shoots were washed with distilled water, dried on filter paper, and weighed to determine the fresh weight (FW). Half of the shoots from each treatment were frozen at $-80{ }^{\circ} \mathrm{C}$ for later biochemical determinations and the other half was 
lyophilized to measure the dry weight (DW) and the ions concentration.

\section{Relative growth rate (RGR) determination}

To determine the relative growth rate (RGR), the shoots from three plants were sampled 7 days after germination. The shoots were dried for $24 \mathrm{~h}$ in a forced-air oven at $70{ }^{\circ} \mathrm{C}$, and DW was registered. Treatments were started 7 days after germination and plants were sampled 21 days after germination ( $T=14$ days). RGR was calculated from the increase in leaf DW at the beginning and the end of the treatments, using the formula:

$\mathrm{RGR}=\left(\ln \mathrm{DW}_{\text {final }}-\ln \mathrm{DW}_{\text {initial }}\right) /(T)$.

\section{Ions concentration determination}

$\mathrm{Zn}, \mathrm{Si}$, and $\mathrm{Ca}$ concentrations were measured using a sample of $150 \mathrm{mg}$ dry material that was mineralized by wet digestion according to Wolf (1982). Dry leaves were ground and mineralized with a mixture of nitric acid $\left(\mathrm{HNO}_{3}\right)$ /perchloric acid $\left(\mathrm{HClO}_{4}\right)$ and $\mathrm{H}_{2} \mathrm{O}_{2}$. After, $20 \mathrm{ml}$ of milli-Q $\mathrm{H}_{2} \mathrm{O}$ was added and the concentrations of elements were measured by ICP-MS (X-Series II; Termo Fisher Scientific Inc., Waltham, MA, USA).

\section{Extraction and $\mathbf{N}$ forms determination and NUE parameters}

The methodology described by Cataldo et al. (1975) was used to determine $\mathrm{NO}_{3}{ }^{-}$concentration. First, $0.1 \mathrm{~g}$ of DW was mixed with $10 \mathrm{ml}$ of Milli-Q water and subjected to aqueous extraction. After, $100 \mu \mathrm{l}$ aliquot was taken and mixed with $10 \%(\mathrm{w} / \mathrm{v})$ salicylic acid in $96 \%$ sulfuric acid. Finally, $\mathrm{NO}_{3}{ }^{-}$concentration was measuring by spectrophotometry.

The Krom (1980) method was used to determine total reduced N. First, a sample of $0.1 \mathrm{~g} \mathrm{DW}$ was digested using $\mathrm{H}_{2} \mathrm{SO}_{4}$ and $\mathrm{H}_{2} \mathrm{O}_{2}$. After, the samples were diluted using Milli-Q water. Then, a $1 \mathrm{ml}$ aliquot was mixed with sodium silicate/sodium nitroprusside and sodium hydroxide and sodium dichloroisocyanurate. Finally, total reduced $\mathrm{N}$ was determined by spectrophotometry. To determine the concentration of soluble $\mathrm{NH}_{4}{ }^{+}$, the same aqueous extracts as for $\mathrm{NO}_{3}{ }^{-}$analysis were processed following the Krom (1980) method.

NUE parameters were calculated as follow:

$\mathrm{N}$ uptake efficiency (NUpE) was calculated as total $\mathrm{N}$ accumulation divided by root DW ( $\mathrm{mg} \mathrm{N} \mathrm{g}^{-1} \mathrm{RDW}$ ).

$\mathrm{N}$ utilization efficiency (NUtE) was calculated as leaf DW divided by $\mathrm{N}$ concentration $\left(\mathrm{g}^{2} \mathrm{LDW} \mathrm{mg} \mathrm{m}^{-1} \mathrm{~N}\right)$.

\section{$\mathrm{N}$ metabolism and photorespiration enzyme extractions and assays}

To determinate nitrate reductase (NR) (EC 1.7.1.1), glutamate dehydrogenase (GDH) (EC 1.4.1.2), and glutamate synthase (GOGAT) (EC 1.4.1.13) activities, leaves were ground at $4{ }^{\circ} \mathrm{C}$ in $50 \mathrm{mM} \mathrm{KH}_{2} \mathrm{PO}_{4}$ buffer ( $\mathrm{pH} 7.5$ ) containing $2 \mathrm{mM}$ dithiothreitol (DTT), $2 \mathrm{mM}$ EDTA, and 1\% (w/v) PVPP. The mix was centrifuged for $20 \mathrm{~min}$ at $30,000 \times g$. The resulting supernatant was used to determine enzymatic activities. NR activity was obtained as in Kaiser and Lewis (1984). GOGAT and GDH activities were determined by measuring the oxidation of NADH at $340 \mathrm{~nm}$, as described by Singh and Srivastava (1986) and Groat and Vance (1981), respectively.

Glutamine synthetase (GS) (EC 6.3.1.2) activity was analyzed using the hydroxamate synthetase assay described by Kaiser and Lewis (1984). First, leaves were ground at $0{ }^{\circ} \mathrm{C}$ in $50 \mathrm{ml}$ maleic acid-KOH buffer $(\mathrm{pH} 6.8)$ containing $20 \%$ (v/v) ethylene glycol, $2 \%$ (v/v) $\beta$-mercaptoethanol, and $100 \mathrm{mM}$ sucrose. Then, the mix was centrifuged at $20 \mathrm{~min}$ for $30,000 \times g$. Finally, GS activity was recorded by spectrophotometry.

Aspartate aminotransferase (AAT) (EC 2.6.1.1) activity was measured reading absorbance at $340 \mathrm{~nm}$ following the Gonzalez et al. (1995) method. The extraction methodology was the same as for GS enzyme. The reaction mixture consisted of $50 \mathrm{mM}$ Tris-HCl buffer (pH 8), $10 \mathrm{mM}$ aspartic acid, $4 \mathrm{mM} \mathrm{MgCl} 2$, and enzyme extract.

The methodology described by Feierabend and Beevers (1972) was followed to determine glyoxylate oxidase (GO) (EC 1.2.3.5) activity. First leaves were ground with $50 \mathrm{mM}$ Tris-HCl buffer (pH 7.8) with $5 \mathrm{mM}$ DTT, $0.01 \%$ Triton $\mathrm{X}-100$ and PVPP. The mix was centrifuged for $20 \mathrm{~min}$ at $30,000 \times g$. The supernatant was used for enzyme reaction and the production of glyoxylate phenylhydrazone was registered at 324 .

For glutamate-glyoxylate aminotransferase (GGAT) (EC 2.6.1.4) activity analysis, the method described by Igarashi et al. (2006) was followed. First, leaves were ground with $100 \mathrm{mM}$ Tris-HCl buffer (pH 7.3) containing $10 \mathrm{mM}$ DTT and $0.1 \%(\mathrm{v} / \mathrm{v})$ Triton $\mathrm{X}-100$. The mix was centrifuged for $10 \mathrm{~min}$ at $20,000 \times g$. The resulting extract was used to determine GGAT activity by coupling the reduction of 2-oxoglutarate by NADH in a reaction catalyzed by GDH.

The protein concentration of the extracts was determined according to the method of Bradford (1976) using bovine serum albumin as the standard. 


\section{Soluble AAs analysis and glycine betaine (GB) determination}

Soluble AAs concentration was determined as in NavarroLeón et al. (2019) using Waters Acquity ${ }^{\circledR}$ UPLC System equipped with an Acquity fluorescence detector.

Glycine betaine (GB) concentration was measured as described by Grieve and Grattan (1983) using dichloroethane and measuring absorbance at $365 \mathrm{~nm}$.

\section{Leaf pigment concentration and SPAD value}

Photosynthetic pigments concentration was obtained using the Wellburn et al. (1994) method with some modifications. First, $0.1 \mathrm{~g}$ of frozen samples was ground in $1 \mathrm{ml}$ of methanol; then the extract was centrifuged for $5 \mathrm{~min}$ at $5000 \times g$. The absorbance was registered at $653 \mathrm{~nm}, 666 \mathrm{~nm}$, and $470 \mathrm{~nm}$. Chlorophyll $a(\mathrm{Chl} a)$, chlorophyll $b(\mathrm{Chl} b)$, and carotenoids concentrations were determined using the Lichtenthaler equation:

Chl $a=15.65 \times \mathrm{A} 666 \mathrm{~nm}-7.34 \mathrm{~A} 653 \mathrm{~nm}$

$\mathrm{Chl} b=27.05 \times \mathrm{A} 653 \mathrm{~nm}-11.21 \times \mathrm{A} 666 \mathrm{~nm}$

Carotenoids $=(1000 \times \mathrm{A} 470 \mathrm{~nm}-2.86 \times \mathrm{Chl}$ $a-129.2 \times \mathrm{Chl} b) / 221$

Total Chl was calculated as the sum of Chl $a$ and $\mathrm{Chl} b$.

The chlorophyll content in the leaves was measured using the chlorophyll meter SPAD-502 (Konica Minolta Sensing Inc, Japan). Three measurements were made per each leaf, nine leaves were analyzed for each treatment and the average of the measurements was calculated.

\section{Chl $a$ fluorescence analysis}

A leaf clip holder was used to kept leaves in the dark for $30 \mathrm{~min}$ before the measurements. Chl $a$ fluorescence kinetics was measured using the Handy PEA Chlorophyll Fluorimeter (Hansatech Ltd., King's Lynn, Norfolk, UK). The fluorescence curves were induced by red light $(650 \mathrm{~nm})$ with $3000 \mu \mathrm{mol}$ photons $\mathrm{m}^{-2} \mathrm{~s}^{-1}$ light intensity and registered by the instrument. The data were analyzed using JIP test. Measurements were performed in fully expanded leaves of six plants at mid-stem position (Strasser et al. 2004). Parameters analyzed to study the energy flow and photosynthetic activities were: initial fluorescence value $\left(F_{\mathrm{O}}\right)$, maximum fluorescence value $(F \mathrm{~m})$, variable fluorescence $\left(F \mathrm{v}=F \mathrm{~m}-F_{\mathrm{o}}\right)$, maximum quantum yield for primary photochemistry $(F \mathrm{v} / F \mathrm{~m})$, a general index of photosynthesis performance $\left(\mathrm{PI}_{\mathrm{ABS}}\right)$, the proportion of active reaction centers (RCs) (RC/ABS), efficiency/probability with which a PSII trapped electron is transferred from $\mathrm{Q}_{\mathrm{A}}-\mathrm{Q}_{\mathrm{B}}\left(\Psi_{0}\right)$, the maximum quantum yield of electron transport $\left(\Phi \mathrm{E}_{\mathrm{o}}\right)$, the time to reach $F \mathrm{~m}$ ( $t$ for $F \mathrm{~m}$ ), area above the fluorescence curve (Area), and fluorescence value at $300 \mu$ s (K step). Besides, electron fluxes per reaction centers were considered: the photon flux absorbed by antenna pigments (ABS/RC), the trapped flow in reaction centers (TRo/RC), and the flow after $\mathrm{Q}_{\mathrm{A}}\left(\mathrm{ET}_{\mathrm{o}} / \mathrm{RC}\right)$ (Strasser et al. 2004).

\section{Statistical analysis}

Data were analyzed with a simple ANOVA at $95 \%$ confidence, using the Statgraphics Centurion XVI program. A two-way ANOVA was applied to ascertain whether the doses of $\mathrm{Zn}$ and $\mathrm{CaSiO}_{3}$ supply significantly affected the results and means were compared by Fisher's least significant differences (LSD). The significance levels for both analyses were expressed as $* P<0.05$, ** $P<0.01$, *** $P<0.001$, or NS (not significant).

\section{Results}

\section{Biomass, RGR and $\mathrm{Zn}, \mathrm{Si}$, and $\mathrm{Ca}$ concentrations}

Plants supplied with the low $\mathrm{Zn}\left(0.01 \mu \mathrm{M} \mathrm{ZnSO}_{4}\right)$, and high $\mathrm{Zn}\left(100 \mu \mathrm{M} \mathrm{ZnSO}_{4}\right)$ doses registered an evident diminution (about 40\%) of leaf DW and RGR compared to control plants $\left(1 \mu \mathrm{M} \mathrm{ZnSO}_{4}\right)$. The application of $\mathrm{CaSiO}_{3}$ to plants grown under both $\mathrm{Zn}$ supplies significantly increased leaf DW and RGR values. In contrast, plants grown under control $\mathrm{Zn}$ dose and $\mathrm{CaSiO}_{3}$ showed a reduction in shoot biomass and RGR in comparison to plants without $\mathrm{CaSiO}_{3}$ (Table 1).

$\mathrm{Zn}$ deficiency decreased leaf $\mathrm{Zn}$ concentration. On the other hand, $100 \mu \mathrm{MnSO}_{4}$ caused a respective $\mathrm{Zn}$ accumulation in plant tissues. $\mathrm{CaSiO}_{3}$ supply did not change $\mathrm{Zn}$ concentration in control plants but enhanced Zn uptake in barley plants supplied with the lowest $\mathrm{Zn}$ dose, presenting similar $\mathrm{Zn}$ concentration than control plants. In addition, $\mathrm{CaSiO}_{3}$ application in plants supplied with the high $\mathrm{Zn}$ dose slightly decreased $\mathrm{Zn}$ concentration. Unsurprisingly, the plants that received $\mathrm{CaSiO}_{3}$ treatment presented higher leaf Si concentration. However, control plants showed higher Si concentration in comparison to the other plants (Table 1). Regarding $\mathrm{Ca}$, plants with $\mathrm{CaSiO}_{3}$ registered higher $\mathrm{Ca}$ concentration regardless of the Zn application (Fig. S1).

\section{$\mathrm{N}$ efficiency parameters}

Plants reduced their NUpE values when supplied with both low and high $\mathrm{Zn}$ doses. This reduction was more important in plants subjected to $\mathrm{Zn}$ deficiency. However, $\mathrm{CaSiO}_{3}$ application was positive for $\mathrm{NUpE}$ in plants grown with $\mathrm{Zn}$ toxicity and deficiency, although $\mathrm{CaSiO}_{3}$ decreased NUpE under control conditions (Fig. 1A). Considering NUtE, both non-optimal $\mathrm{Zn}$ conditions increased the values of this parameter in comparison to control 
Table 1 Effects of different $\mathrm{Zn}$ doses and the presence $(+\mathrm{Si})$ or absence $(-\mathrm{Si})$ of $\mathrm{CaSiO}_{3}$ supply on leaf biomass, leaf RGR, and $\mathrm{Zn}$ and $\mathrm{Si}$ concentrations in barley leaves

\begin{tabular}{|c|c|c|c|c|c|c|c|c|c|c|c|c|}
\hline \multirow[b]{2}{*}{$\mu \mathrm{M} \mathrm{Zn}$} & \multicolumn{3}{|c|}{ Leaf DW (mg DW) } & \multicolumn{3}{|c|}{ Leaf RGR (mg/day) } & \multicolumn{3}{|c|}{ Leaf $\mathrm{Zn}\left(\mu \mathrm{g} \mathrm{g}^{-1} \mathrm{DW}\right)$} & \multicolumn{3}{|c|}{$\begin{array}{l}\text { Leaf Si } \\
\left(\mathrm{mg} \mathrm{g}^{-1} \mathrm{DW}\right)\end{array}$} \\
\hline & 0.01 & 1 & 100 & 0.01 & 1 & 100 & 0.01 & 1 & 100 & 0.01 & 1 & 100 \\
\hline$-\mathrm{Si}$ & 24.10 & 41.12 & 26.61 & 0.08 & 0.14 & 0.07 & 13.50 & 22.51 & 123.18 & 0.78 & 1.57 & 1.26 \\
\hline$+\mathrm{Si}$ & 32.09 & 30.61 & 31.79 & 0.09 & 0.08 & 0.09 & 18.00 & 24.00 & 109.53 & 3.22 & 3.49 & 2.57 \\
\hline$p$-value & $*$ & $*$ & $*$ & $*$ & $*$ & $*$ & $*$ & NS & $*$ & * & $*$ & $*$ \\
\hline $0.01 \mu \mathrm{M} \mathrm{Zn}$ & & $28.10 \mathrm{~b}$ & & & 0.0911 & & & $15.75 \mathrm{c}$ & & & $2.00 \mathrm{~b}$ & \\
\hline $1 \mu \mathrm{M} \mathrm{Zn}$ & & $35.85 a$ & & & 0.098 & & & $20.25 b$ & & & $2.53 \mathrm{a}$ & \\
\hline $100 \mu \mathrm{M} \mathrm{Zn}$ & & $29.21 b$ & & & 0.082 & & & $116.25 \mathrm{a}$ & & & $1.91 \mathrm{~b}$ & \\
\hline $\mathrm{LSD}_{0.05}$ & & 1.88 & & & 0.001 & & & 3.02 & & & 0.18 & \\
\hline
\end{tabular}

Values are means $(n=9)$ and differences between means were compared by Fisher's least-significance test (LSD; $P=0.05$ ). The upper part of the table shows the effect of $\mathrm{CaSiO}_{3}$ application and the lower part shows the effect of $\mathrm{Zn}$ doses. Values with different letters indicate significant differences. The levels of significance were represented by NS $(P>0.05)$ and $*(P<0.05)$
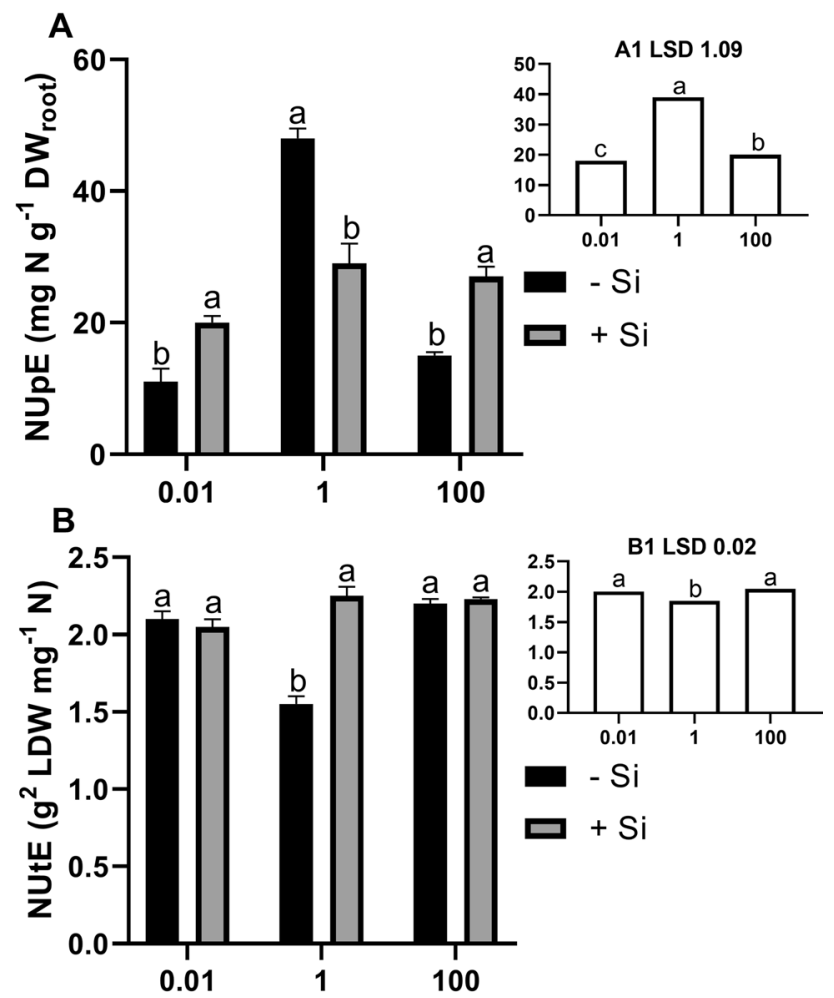

Fig. 1 Effects of $\mathrm{Zn}$ dose and the presence $(+\mathrm{Si})$ or absence $(-\mathrm{Si})$ of $\mathrm{CaSiO}_{3}$ supply on NUpE (A), and NUtE (B) in barley leaves. The columns values are mean \pm standard error $(n=9)$, the differences between means were compared with the minimum significant difference of Fisher's test (LSD; $P=0.05)$. A1 and B1 values are means (control + Si supply $n=18$ ). Different letters indicate significative differences between plants supplied with $\mathrm{CaSiO}_{3}$ and plants without $\mathrm{CaSiO}_{3}$

conditions. NUtE value was higher in plants grown under control conditions with $\mathrm{CaSiO}_{3}$ than in plants without $\mathrm{CaSiO}_{3}$. In contrast, $\mathrm{CaSiO}_{3}$ application did not modify
NUtE value in barley plants supplied with non-optimal Zn doses (Fig. 1B).

\section{$\mathrm{NH}_{4}{ }^{+}$production: $\mathrm{NO}_{3}{ }^{-}$reduction and photorespiration}

$\mathrm{Zn}$ deficiency caused an increment of $\mathrm{NO}_{3}{ }^{-}$concentration in barley plants. Likewise, $\mathrm{CaSiO}_{3}$ increased $\mathrm{NO}_{3}{ }^{-}$in barley grown under control and $\mathrm{Zn}$-deficient conditions. Similarly, but to a lesser extent, $\mathrm{CaSiO}_{3}$ supply increased $\mathrm{NO}_{3}{ }^{-}$concentration in $\mathrm{Zn}$-toxicity plants. Interestingly, $\mathrm{Zn}$ dose did not affect to NR activity, although $\mathrm{CaSiO}_{3}$ application raised NR activity in plants grown under control and deficient $\mathrm{Zn}$ doses. Nevertheless, a significant diminution was detected in plants subjected to $\mathrm{Zn}$ toxicity compared to plants that did not receive $\mathrm{CaSiO}_{3}$. Besides, free $\mathrm{NH}_{4}{ }^{+}$ levels increased in plants supplied with $0.01 \mu \mathrm{M} \mathrm{ZnSO}_{4}$ and $100 \mu \mathrm{M} \mathrm{ZnSO}$. However, $\mathrm{CaSiO}_{3}$ enhanced $\mathrm{NH}_{4}{ }^{+}$ concentration in plants supplied with and $1 \mu \mathrm{M} \mathrm{ZnSO}_{4}$, $100 \mu \mathrm{M} \mathrm{ZnSO}_{4}$, whereas reduced it in plants grown with $0.01 \mu \mathrm{M} \mathrm{ZnSO}$. Total reduced $\mathrm{N}$ concentration was lower in plants supplied with non-optimal $\mathrm{Zn}$ doses compared to control plants. In contrast, $\mathrm{CaSiO}_{3}$ application was positive to increased total reduced $\mathrm{N}$ in these plants (Table 2). Considering photorespiratory enzymes, GO and GGAT showed higher activities in plants grown under non-optimal $\mathrm{Zn}$ doses, compared to control conditions (Fig. 2). $\mathrm{CaSiO}_{3}$ application increased $\mathrm{GO}$ activity in control plants, whereas caused a reduction in plants that received the rest of $\mathrm{Zn}$ doses (Fig. 2A). Differently, $\mathrm{CaSiO}_{3}$ effects were unequally on GGAT activity depending on the $\mathrm{Zn}$ dose: it was lower in Zn-deficient plants but increased in control plants, whereas it did not cause effects in plants grown with $100 \mu \mathrm{M} \mathrm{ZnSO}_{4}$ (Fig. 2B). 


\section{$\mathrm{NH}_{4}{ }^{+}$incorporation and assimilation products}

GDH, GOGAT, and GS activities increased in comparison to controls in plants supplied with under both $\mathrm{Zn}$ toxicity and deficiency doses. Conversely, $\mathrm{CaSiO}_{3}$ application caused inhibition of these activities in $\mathrm{Zn}$-stressed plants. AAT activity increased almost two-fold in plants supplied with 0.01 and $100 \mu \mathrm{M} \mathrm{ZnSO}_{4}$ compared to controls. Moreover, $\mathrm{CaSiO}_{3}$ decreased AAT activity in Zn-deficient plants, did not change in Zn-toxicity barley plants, whereas in control plants $\mathrm{CaSiO}_{3}$ increased AAT activity (Table 3).

\section{$\mathbf{N}$ derived protective compounds concentration}

Pro and GB concentrations increased with $\mathrm{Zn}$ stress in barley leaves. Conversely, control plants showed low levels of both compounds compared to the other treatments. Pro levels decreased in plants grown with $\mathrm{CaSiO}_{3}$ and non-optimal $\mathrm{Zn}$ doses, although in control conditions, $\mathrm{CaSiO}_{3}$ application increased Pro concentration. In contrast, the $\mathrm{CaSiO}_{3}$ application did change GB content compared to plants without $\mathrm{CaSiO}_{3}$ (Fig. 3).

\section{AAs concentration}

$\mathrm{Zn}$ toxicity increased total free AAs, whereas $\mathrm{CaSiO}_{3}$ application reduced total AAs regardless of the $\mathrm{Zn}$ dose applied. However, Zn deficiency did not affect AAs profile except by an increment in Tyr concentration. Furthermore, $\mathrm{Zn}$ toxicity increased the majority of AAs concentration except for Cys, Arg, Tyr, and Gly that did not change compared to control $\mathrm{Zn}$ supply. $\mathrm{CaSiO}_{3}$ application reduced the concentration of most AAs, especially in barley grown under $1 \mu \mathrm{M} \mathrm{ZnSO}_{4}$ dose. $\mathrm{CaSiO}_{3}$ increased Pro concentration in plants supplied with $0.01 \mu \mathrm{M} \mathrm{ZnSO}_{4}$ dose and did not change Asp, Glu, and Tyr concentrations. In control plants, Asp and Arg did not change, whereas Tyr concentration increased in plants
A
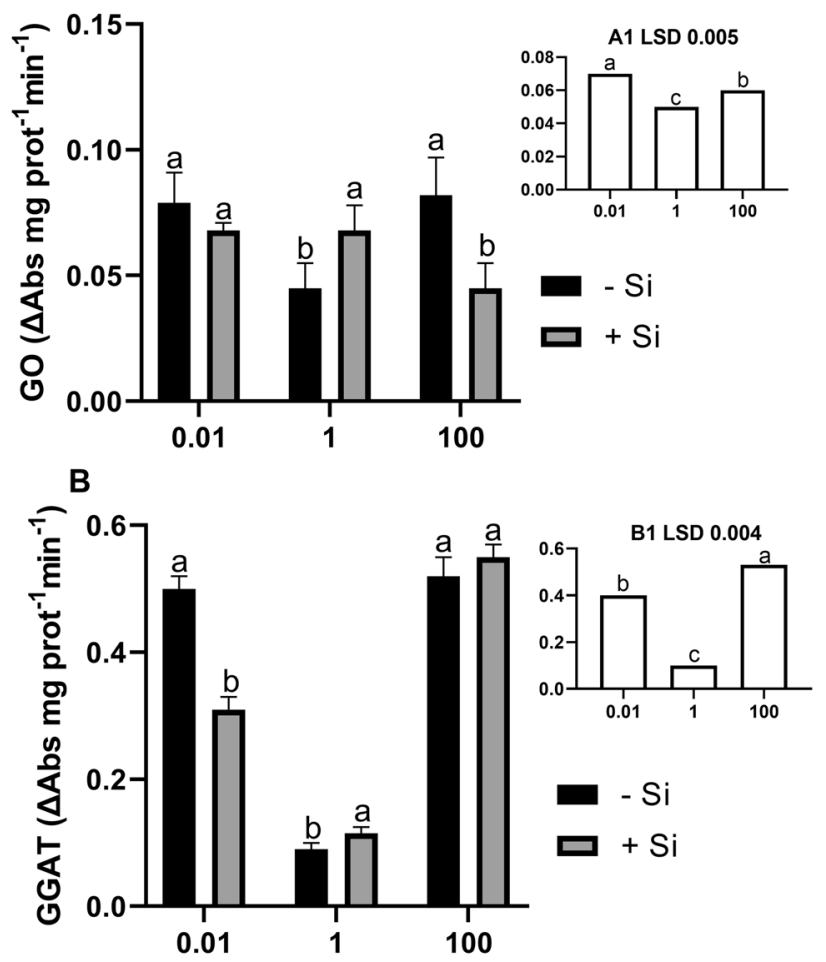

Fig. 2 Effects of $\mathrm{Zn}$ dose and the presence $(+\mathrm{Si})$ or absence $(-\mathrm{Si})$ of $\mathrm{CaSiO}_{3}$ supply on GO (A), and GGAT (B) in barley leaves. The column's values are mean \pm standard error $(n=9)$, the differences between means were compared with the minimum significant difference of Fisher's test (LSD; $P=0.05$ ). A1 and B1 values are means (control + Si supply $n=18$ ). Different letters indicate significative differences between plants supplied with $\mathrm{CaSiO}_{3}$ and plants without $\mathrm{CaSiO}_{3}$

with $\mathrm{CaSiO}_{3}$. Finally, in barley grown under $\mathrm{Zn}$ toxicity, Glu, Cys, His and Gly concentrations did not change when $\mathrm{CaSiO}_{3}$ was applied, whereas Tyr concentration increased (Fig. 4A; Table S1).
Table $2 \mathrm{~N}$ forms and NR activity in barley plants grown under different $\mathrm{Zn}$ doses, and with the presence $(+\mathrm{Si})$ or absence $(-\mathrm{Si})$ of $\mathrm{CaSiO}_{3}$

\begin{tabular}{|c|c|c|c|c|c|c|c|c|c|c|c|c|}
\hline \multirow[b]{2}{*}{$\mu \mathrm{M} Z \mathrm{Zn}$} & \multicolumn{3}{|c|}{$\mathrm{NO}_{3}^{-}\left(\mathrm{mg} \mathrm{g}^{-1} \mathrm{DW}\right)$} & \multicolumn{3}{|c|}{$\begin{array}{l}\mathrm{NR}\left(\mu \mathrm{M} \mathrm{NO}{ }_{2}\right. \\
\left.\mathrm{mg}_{\operatorname{prot}^{-1}} \min ^{-1}\right)\end{array}$} & \multicolumn{3}{|c|}{$\mathrm{NH}_{4}^{+}\left(\mathrm{mg} \mathrm{g}^{-1} \mathrm{DW}\right)$} & \multicolumn{3}{|c|}{$\begin{array}{l}\text { Total reduced N } \\
\left(\mathrm{mg} \mathrm{g}^{-1} \mathrm{DW}\right)\end{array}$} \\
\hline & 0.01 & 1 & 100 & 0.01 & 1 & 100 & 0.01 & 1 & 100 & 0.01 & 1 & 100 \\
\hline$-\mathrm{Si}$ & 2.42 & 1.89 & 2.37 & 0.27 & 0.27 & 0.33 & 1.96 & 1.44 & 1.68 & 7.60 & 22.01 & 10.59 \\
\hline$+\mathrm{Si}$ & 3.86 & 3.03 & 2.96 & 0.32 & 0.32 & 0.25 & 1.68 & 1.52 & 1.91 & 10.42 & 13.73 & 14.98 \\
\hline$p$-value & $*$ & $*$ & $*$ & $*$ & $*$ & $*$ & $*$ & $*$ & $*$ & $*$ & $*$ & $*$ \\
\hline $0.01 \mathrm{Zn}$ & & $3.14 \mathrm{a}$ & & & $0.29 a$ & & & $1.82 \mathrm{a}$ & & & $9.01 \mathrm{~b}$ & \\
\hline $1 \mathrm{Zn}$ & & $2.46 \mathrm{~b}$ & & & $0.30 \mathrm{a}$ & & & $1.49 \mathrm{~b}$ & & & $17.87 \mathrm{a}$ & \\
\hline $100 \mathrm{Zn}$ & & $2.67 \mathrm{~b}$ & & & $0.29 \mathrm{a}$ & & & $1.79 \mathrm{a}$ & & & $10.39 b$ & \\
\hline $\operatorname{LSD}_{0.05}$ & & 0.25 & & & 0.01 & & & 0.05 & & & 1.85 & \\
\hline
\end{tabular}

Values are means $(n=9)$ and differences between means were compared by Fisher's least-significance test (LSD; $P=0.05$ ). The upper part of the table shows the effect of $\mathrm{CaSiO}_{3}$ application and the lower part shows the effect of $\mathrm{Zn}$ doses. Values with different letters indicate significant differences. The levels of significance were represented by NS $(P>0.05)$ and $*(P<0.05)$ 


\section{SPAD value and photosynthetic pigments}

Both low and high $\mathrm{Zn}$ doses reduced SPAD value of barley plants compared to control conditions. Although, $\mathrm{CaSiO}_{3}$ supply substantially restored SPAD values to control plant levels. Likewise, photosynthetic pigments concentration was significantly affected by $\mathrm{Zn}$ dose. Thus, low and high $\mathrm{Zn}$ concentrations decreased $\mathrm{Chl} a$ and $\mathrm{Chl} b$ concentrations. When $\mathrm{CaSiO}_{3}$ was added, $\mathrm{Chl}$ levels increased in both control and $\mathrm{Zn}$-deficient plants, whereas $\mathrm{CaSiO}_{3}$ did not produce effects in plants supplied with the highest $\mathrm{Zn}$ dose. The Chl $a / b$ results presented no significant changes comparing the three $\mathrm{Zn}$ doses. Nevertheless, in barley plants grown with $\mathrm{CaSiO}_{3}$ and the high $\mathrm{Zn}$ dose, the $\mathrm{Chl}$ $a / b$ values were higher than in plants without $\mathrm{CaSiO}_{3}$. In contrast, $\mathrm{CaSiO}_{3}$ did not modify $\mathrm{Chl} a / b$ values. Regarding controls, carotenoids levels increased in plants supplied with $0.01 \mu \mathrm{M} \mathrm{ZnSO}$ and did differ in plants subjected to $\mathrm{Zn}$ excess. $\mathrm{CaSiO}_{3}$ application did not produce effects in carotenoids concentration in $\mathrm{Zn}$-deficient plants but induced a significant increase in both control and $\mathrm{Zn}$ toxicity plants (Table 4).

\section{Effects of $\mathrm{Zn}$ nutrition and $\mathrm{CaSiO}_{3}$ supply on $\mathrm{Chl} \mathrm{a}$ fluorescence parameters}

No significant differences in $F \mathrm{O}, F \mathrm{~m}, F \mathrm{v} / F \mathrm{~m}, \mathrm{PI}_{\mathrm{ABS}}, \mathrm{RC} / \mathrm{ABS}$, and $\mathrm{K}$ step parameters were observed between the different $\mathrm{Zn}$ supplies. However, non-optimal $\mathrm{Zn}$ levels reduced the values of $\Psi_{\mathrm{Eo}}, t$ for $F \mathrm{~m}$, Area, ABS/RC, and ET/RC. Furthermore, $\Phi_{\mathrm{Eo}}$ suffered a reduction lower in plants grown under $100 \mu \mathrm{M}$ $\mathrm{ZnSO}_{4} \mathrm{Zn}$, whereas TR/RC decreased in $\mathrm{Zn}$-deficient plants. $\mathrm{CaSiO}_{3}$ supply lowered $F_{\mathrm{o}}$ value in plants grown with $0.01 \mu \mathrm{M}$ $\mathrm{ZnSO}_{4}$ but enhanced it in plants supplied with 1 and $100 \mu \mathrm{M}$ $\mathrm{ZnSO}_{4}$. In $\mathrm{Zn}$-deficient plants, $\mathrm{CaSiO}_{3}$ increased $\mathrm{Fm}$ value but decreased it in control plants. $\mathrm{CaSiO}_{3}$ application incremented $\mathrm{Fv} / F \mathrm{~m}$ in plants grown under non-optimal $\mathrm{Zn}$ supplies. Irrespective of the $\mathrm{Zn}$ dose applied, $\mathrm{CaSiO}_{3}$ increased the values of $\mathrm{PI}_{\mathrm{ABS}}, \mathrm{RC} / \mathrm{ABS}, \Psi_{\mathrm{E}}, \Phi_{\mathrm{E} 0}, t$ for $F \mathrm{~m}$, and Area, whereas it reduces the $\mathrm{K}$ step value compared to plants without $\mathrm{CaSiO}_{3}$. Finally, $\mathrm{CaSiO}_{3}$ also increased electron fluxed in control and $\mathrm{Zn}$-toxicity plants but not in Zn-deficient ones that presented lower ABS/RC and TR/RC values (Fig. 4B; Table S2).

\section{Discussion}

Plant growth is related to leaf DW and RGR that represents the best parameters to estimate stress effects on plants (Gong et al. 2013). Hajiboland and Amirazad (2010) observed a decrease in leaf biomass of up to $62 \%$ in $\mathrm{Zn}$ deficient Brassica oleracea plants. Furthermore, the exposition to toxic $\mathrm{Zn}$ concentration causes its accumulation in tissues reducing plant biomass (Gisbert et al. 2006). Likewise, in our study, barley plants suffering from $\mathrm{Zn}$ deficiency and $\mathrm{Zn}$ toxicity reduced their biomass and growth. However, the $\mathrm{CaSiO}_{3}$ application mitigated the loss of biomass in $\mathrm{Zn}$-deficient and $\mathrm{Zn}$-toxicity plants. These results suggest a positive effect of $\mathrm{CaSiO}_{3}$, which mitigates the biomass loss caused by low or high $\mathrm{Zn}$ presence. Among the elements provided by $\mathrm{CaSiO}_{3}, \mathrm{Si}$ could be responsible for this positive effect, but not $\mathrm{Ca}$ because it did not increase its accumulation in barley plants. Thus, $\mathrm{CaSiO}_{3}$ improved $\mathrm{Zn}$ accumulation in $\mathrm{Zn}$-deficient barley plants and reduced $\mathrm{Zn}$ concentration in $\mathrm{Zn}$-toxicity plants. A similar positive effect of $\mathrm{Si}$ was observed in rice plants grown under high $\mathrm{Zn}$ doses and in soybean subjected to $\mathrm{Zn}$ shortage (Song et al. 2014; Pascual et al. 2016). However, in the present study, $\mathrm{CaSiO}_{3}$ reduced the growth in control plants, so a higher Si accumulation may be unfavorable in control conditions. Besides, the lower $\mathrm{N}$ uptake may reduce growth in these plants.

Smirnnoff and Stewart (1987) proved that low Zn reduces the presence of reduced $\mathrm{N}$ compounds. Accordingly, NUpE decreased in our barley plants grown under non-optimal $\mathrm{Zn}$ supplies indicating that $\mathrm{Zn}$ stress affects $\mathrm{N}$ uptake. However, NUtE increased in these plants, suggesting that $\mathrm{Zn}$ stress could balance the reduction in $\mathrm{N}$ availability by an increase of $\mathrm{N}$ utilization efficiency. Moreover, $\mathrm{NUpE}$ values suggested that $\mathrm{CaSiO}_{3}$ reduced the effects of $\mathrm{Zn}$ deficiency and toxicity through a higher $\mathrm{N}$ accumulation. In control plants, despite the lower NUpE, a higher NUtE was observed, probably as a result of the higher $\mathrm{NO}_{3}{ }^{-}$and $\mathrm{NH}_{4}{ }^{+}$concentrations and the increment in NR activity. Previous studies described inhibition of NR in Zn-deficient (Seethambaram and Das 1986) and plants grown under $\mathrm{Zn}$ toxicity (Luna et al. 2000). In our experiment, $\mathrm{NO}_{3}{ }^{-}$concentration increased under $\mathrm{Zn}$ stress, despite NR activity did not show changes and it was a lower $\mathrm{N}$ uptake. A diversion of reductants from basal metabolism to stress response could be a possible explanation (Esposito 2016). On the other hand, in plants affected by $\mathrm{Zn}$ deficiency, $\mathrm{CaSiO}_{3}$ enhanced NR activity probably through an increase of $\mathrm{NO}_{3}{ }^{-}$concentration.

Besides from $\mathrm{NO}_{3}{ }^{-}$reduction, $\mathrm{NH}_{4}{ }^{+}$is continuously produced by photorespiration (Wingler et al. 2000). In the present experiment, $\mathrm{Zn}$ shortage and excess enhanced photorespiratory enzyme activities, suggesting that an increased photorespiration helps in ROS elimination to counteract the oxidative burst under $\mathrm{Zn}$ stress (Wingler et al. 2000). Nevertheless, the results in barley plants suggest that $\mathrm{CaSiO}_{3}$ could inhibit photorespiration in the $\mathrm{Zn}$-stressed plants, which suggests a lower stress in these plants. Furthermore, $\mathrm{NH}_{4}{ }^{+}$assimilatory enzymes showed higher activities in plants grown under nonoptimal $\mathrm{Zn}$ doses. An increment of GS activity could 
Table 3 Activities of $\mathrm{N}$ metabolism enzymes in barley plants grown under different $\mathrm{Zn}$ doses, and with the presence $(+\mathrm{Si})$ or absence $(-\mathrm{Si})$ of $\mathrm{CaSiO}_{3}$

\begin{tabular}{|c|c|c|c|c|c|c|c|c|c|c|c|c|}
\hline \multirow[b]{2}{*}{$\mu \mathrm{M} \mathrm{Zn}$} & \multicolumn{3}{|c|}{$\begin{array}{l}\text { GS ( } \mu \mathrm{M} \text { glutamyl hydroxamate } \\
\left.\mathrm{mg} \operatorname{prot}^{-1} \min ^{-1}\right)\end{array}$} & \multicolumn{3}{|c|}{$\begin{array}{l}\text { GOGAT } \\
\left(\Delta \text { Abs mg } \operatorname{prot}^{-1} \min ^{-1}\right)\end{array}$} & \multicolumn{3}{|c|}{$\begin{array}{l}\text { GDH } \\
\left(\Delta \text { Abs mg } \operatorname{prot}^{-1} \min ^{-1}\right)\end{array}$} & \multicolumn{3}{|c|}{ AAT $\left(\Delta\right.$ Abs mg $\left.\operatorname{prot}^{-1} \min ^{-1}\right)$} \\
\hline & 0.01 & 1 & 100 & 0.01 & 1 & 100 & 0.01 & 1 & 100 & 0.01 & 1 & 100 \\
\hline$-\mathrm{Si}$ & 516.75 & 310.69 & 816.07 & 1.80 & 0.96 & 1.52 & 0.14 & 0.08 & 0.36 & 7.60 & 22.01 & 10.59 \\
\hline$+\mathrm{Si}$ & 370.61 & 368.54 & 441.71 & 1.42 & 1.01 & 1.19 & 0.39 & 0.20 & 0.49 & 10.42 & 13.73 & 14.98 \\
\hline$p$-value & $*$ & $*$ & $*$ & $*$ & NS & * & $*$ & $*$ & $*$ & $*$ & $*$ & * \\
\hline $0.01 \mathrm{Zn}$ & $443.68 b$ & & & $1.61 \mathrm{a}$ & & & $0.27 b$ & & & $9.01 \mathrm{c}$ & & \\
\hline $1 \mathrm{Zn}$ & $339.62 \mathrm{c}$ & & & $1.04 \mathrm{c}$ & & & $0.14 \mathrm{c}$ & & & $17.87 \mathrm{a}$ & & \\
\hline $100 \mathrm{Zn}$ & $628.89 \mathrm{a}$ & & & $1.29 b$ & & & $0.43 \mathrm{a}$ & & & $12.76 \mathrm{~b}$ & & \\
\hline $\mathrm{LSD}_{0.05}$ & 36.09 & & & 0.11 & & & 0.01 & & & 0.93 & & \\
\hline
\end{tabular}

Values are means $(n=9)$ and differences between means were compared by Fisher's least-significance test (LSD; $P=0.05)$. The upper part of the table shows the effect of $\mathrm{CaSiO}_{3}$ application and the lower part shows the effect of $\mathrm{Zn}$ doses. Values with different letters indicate significant differences. The levels of significance were represented by NS $(P>0.05)$ and $*(P<0.05)$

induce a higher use of Glu and Gln generated from the GS/GOGAT cycle and afterward the formation of aspartate (Asp) and other essential AAs by the AAT activity (De la Torre et al. 2014). However, this increased AAs synthesis was not enough to counteract $\mathrm{Zn}$ stress. In addition, $\mathrm{CaSiO}_{3}$ reduced $\mathrm{GS}$ activity to control values. These results suggest a decrease of $\mathrm{NH}_{4}{ }^{+}$recycling through photorespiration, and therefore a reduction of stress symptoms. Besides, GDH also participates in $\mathrm{NH}_{4}{ }^{+}$assimilation when is present in a high concentration in plant cells (Robinson et al. 1991). Thus, in our experiment, $\mathrm{CaSiO}_{3}$ enhanced GDH activity, which probably contributes to $\mathrm{NH}_{4}{ }^{+}$assimilation.

Under stress, plants usually increase total AAs concentration because of an increment of the protein degradation/ synthesis ratio (Atilio and Causin 1996). Thus, specific stress-related AAs, such as Pro, are accumulated in plant tissues (Ashraf and Foolad 2007). This increase was observed in our experiment in barley plants subjected to $\mathrm{Zn}$ excess. Indeed, these plants presented a remarkable increment of Asp and Ser, probably as a response to the increased photorespiration activity. On the other hand, $\mathrm{CaSiO}_{3}$ reduced AAs levels, suggesting lower proteolysis due to reduced stress symptoms. However, plants did not reduce basic AAs involved in $\mathrm{N}$ metabolism, such as Asp and Glu. Likewise, AAs composing GSH did not decrease under Zn toxicity, probably to synthesize more GSH to improve $\mathrm{Zn}$ homeostasis. In addition, $\mathrm{CaSiO}_{3}$ application only increased $\mathrm{Tyr}$ concentration, which might be due to an enhancement of Tyr metabolism produced by $\mathrm{Zn}$ imbalance to synthesize tocopherol and related antioxidant compounds (Holländer-Czytko et al. 2005). Regarding Pro, other experiments showed that Zn toxicity increases this AA (Höller et al. 2013; Paradisone et al. 2015), which agree with our results. Likewise, Navarro-León et al. (2016) observed higher GB levels in
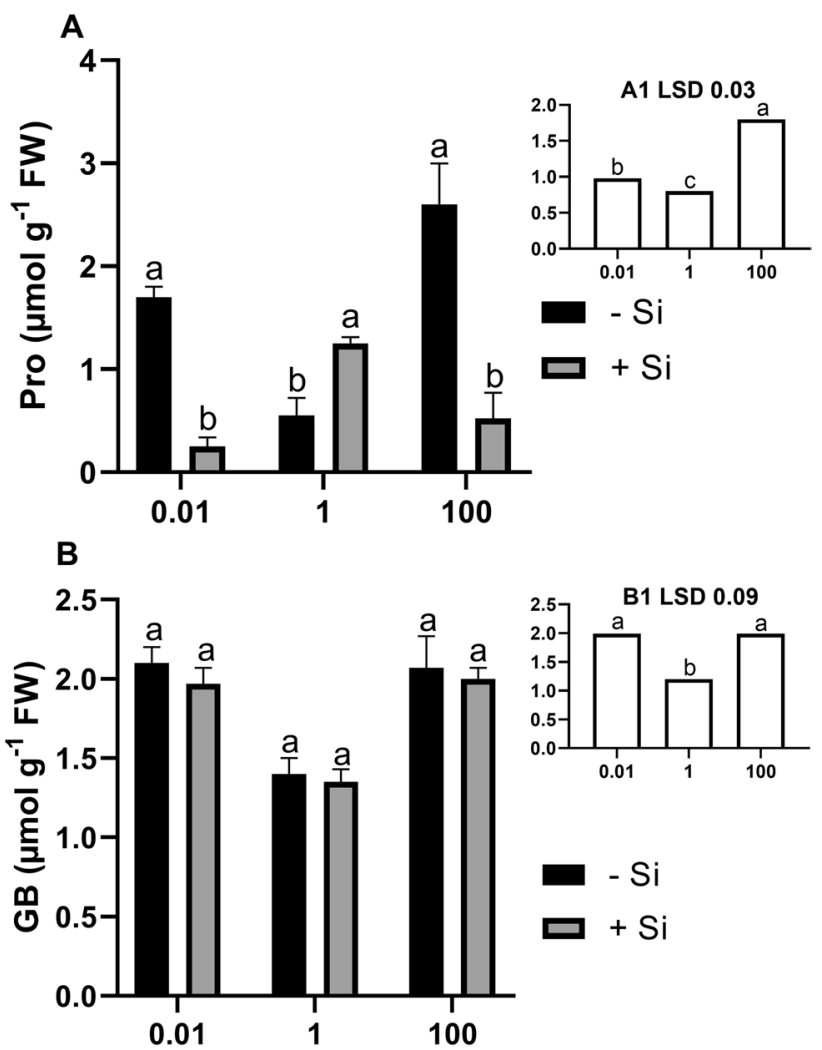

Fig. 3 Effects of $\mathrm{Zn}$ dose and the presence $(+\mathrm{Si})$ or absence $(-\mathrm{Si})$ of $\mathrm{CaSiO}_{3}$ on Pro (A), and GB contents (B) in barley leaves. The columns values are mean \pm standard error $(n=9)$, the differences between means were compared with the minimum significant difference of Fisher's test (LSD; $P=0.05$ ). A1 and B1 values are means (control $+\mathrm{Si}$ supply $n=18$ ). Different letters indicate significative differences between plants supplied with $\mathrm{CaSiO}_{3}$ and plants without $\mathrm{CaSiO}_{3}$

Zn-deficient cabbage plants. Similarly, in the present experiment, GB levels increased in Zn-deficient barley plants. 
Fig. 4 Radar chart showing the AAs profile (A) and analyzed parameters of Chl $a$ fluorescence $(\mathbf{B})$ of barley plants subjected to the six different treatments. Actual values were normalized to show in the same range

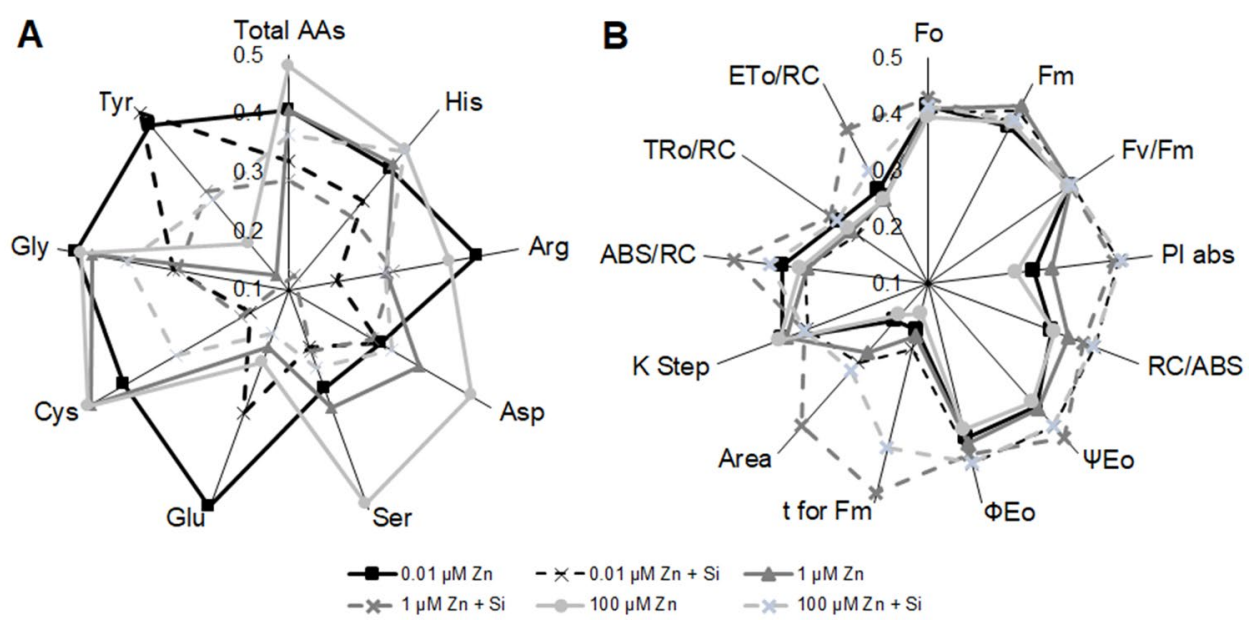

\begin{tabular}{|c|c|c|c|c|c|c|c|c|c|c|c|c|}
\hline \multirow[b]{2}{*}{$\mu \mathrm{M} Z \mathrm{Zn}$} & \multicolumn{3}{|l|}{ SPAD } & \multicolumn{3}{|c|}{ Chl $a\left(\mathrm{mg} \mathrm{g}^{-1} \mathrm{FW}\right)$} & \multicolumn{3}{|c|}{$\mathrm{Chl} b\left(\mathrm{mg} \mathrm{g}^{-1} \mathrm{FW}\right)$} & \multicolumn{3}{|c|}{$\begin{array}{l}\text { Carotenoids ( } \mathrm{mg} \mathrm{g}^{-1} \\
\text { FW) }\end{array}$} \\
\hline & 0.01 & 1 & 100 & 0.01 & 1 & 100 & 0.01 & 1 & 100 & 0.01 & 1 & 100 \\
\hline$-\mathrm{Si}$ & 26.63 & 44.40 & 27.42 & 0.19 & 0.19 & 0.16 & 0.08 & 0.08 & 0.07 & 0.03 & 0.02 & 0.01 \\
\hline$+\mathrm{Si}$ & 43.27 & 43.73 & 37.71 & 0.20 & 0.20 & 0.16 & 0.09 & 0.09 & 0.07 & 0.03 & 0.03 & 0.02 \\
\hline$p$-value & $*$ & NS & $*$ & $*$ & $*$ & NS & * & $*$ & NS & NS & $*$ & $*$ \\
\hline $0.01 \mathrm{Zn}$ & & $34.95 b$ & & $0.195 b$ & & & $0.088 \mathrm{a}$ & & & $0.027 \mathrm{a}$ & & \\
\hline $1 \mathrm{Zn}$ & & $44.08 \mathrm{a}$ & & $0.201 \mathrm{a}$ & & & $0.088 \mathrm{a}$ & & & $0.024 \mathrm{~b}$ & & \\
\hline $100 \mathrm{Zn}$ & & $32.56 \mathrm{c}$ & & $0.166 \mathrm{c}$ & & & $0.073 b$ & & & $0.021 \mathrm{c}$ & & \\
\hline $\mathrm{LSD}_{0.05}$ & & 0.57 & & 0.003 & & & 0.002 & & & 0.001 & & \\
\hline
\end{tabular}

Values are means $(n=9)$ and differences between means were compared by Fisher's least-significance test (LSD; $P=0.05$ ). The upper part of the table shows the effect of $\mathrm{CaSiO}_{3}$ application and the lower part shows the effect of $\mathrm{Zn}$ doses. Values with different letters indicate significant differences. The levels of significance were represented by NS $(P>0.05)$ and $*(P<0.05)$
Because barley is sensitive to $\mathrm{Zn}$ imbalances, our results suggest that GB and Pro accumulations represent a stress indicator, instead of a tolerance mechanism. Accordingly, the lower Pro accumulation in $\mathrm{CaSiO}_{3}$ plants suggests lower stress in these plants.

Photosynthesis is a sensitive process to stress (Pfannschmidt and Yang 2012). Thus, plants grown under non-optimal $\mathrm{Zn}$ doses presented lower Chls and SPAD levels, which agree with previous research (Song et al. 2014; Pascual et al. 2016). Our SPAD results suggested that $\mathrm{CaSiO}_{3}$ supply protected barley plants against the chlorosis originated by the $\mathrm{Zn}$ imbalances. Accordingly, other studies also noted this positive effect of $\mathrm{CaSiO}_{3}$ on photosynthetic pigments (Song et al. 2014; Pascual et al. 2016). Furthermore, carotenoids play a central role as antioxidant compounds removing ROS (Havaux 1998). Low $\mathrm{Zn}$ application promoted the accumulation of these pigments, probably as a response to stress, which was also observed by Hajiboland and Amirazad (2010) in B. oleracea plants subjected to $\mathrm{Zn}$ deficiency. Besides, $\mathrm{CaSiO}_{3}$ has a positive effect on carotenoids concentration in barley plants, as also observed by Anwaar et al. (2015) in cotton plants. A high carotenoid content could be useful to increase antioxidant properties of food (Nicolle et al. 2004).

Chl $a$ fluorescence is important to dissipate the energy excess in photosynthetic tissues (Strasser et al. 2004). The effects of $\mathrm{Zn}$ imbalances on $\mathrm{Chl} a$ fluorescence parameters vary depending on the species, although photosynthesis performance is usually negatively affected (Hajiboland and Amirazad 2010; Zhao and Wu 2017). Fluorescence parameters suggest that neither $\mathrm{Zn}$ deficiency nor toxicity caused remarkable effects on PSII performance, as indicative parameters, such as $\mathrm{PI}_{\mathrm{ABS}}$ and $\mathrm{RC} / \mathrm{ABS}$, were unaffected by these $\mathrm{Zn}$ doses. However, parameters, such as $\Psi_{\mathrm{E}}, t$ for $F \mathrm{~m}$, Area, and electron fluxes, were negatively affected. In addition, $\mathrm{Zn}$ deficiency affected to a greater extent to photosynthesis performance compared to $\mathrm{Zn}$ toxicity as shown by the values of $t$ for $F \mathrm{~m}$, and $\mathrm{ABS} / \mathrm{RC}$ and TR/RC parameters. Moreover, $\mathrm{Zn}$ toxicity reduced $\Psi_{0}$ and $\Phi_{\mathrm{Eo}}$, which suggests lower electron transport activity due to the accumulation of reduced $\mathrm{Q}^{-}$. 
Regarding the $\mathrm{CaSiO}_{3}$ application, other authors observed that $\mathrm{Si}$ enhance $F \mathrm{v} / F \mathrm{~m}$ and electron transport (Sivanesan et al. 2011; Song et al. 2014). In our experiment, $\mathrm{CaSiO}_{3}$ had a positive effect on PSII performance as it increased almost all parameters. Therefore, $\mathrm{CaSiO}_{3}$ increased the proportion of active RCs, the energy flux through PSII, the pool of $\mathrm{Q}^{-}$, and thus, the energy for photosynthesis. Likewise, $\mathrm{CaSiO}_{3}$ reduced $\mathrm{K}$ step values, which suggest better electron flux between the OEC and the PSII.

\section{Conclusion}

Barley plants subjected to $\mathrm{Zn}$ shortage and $\mathrm{Zn}$ excess presented an inhibition of growth that could be caused by lower $\mathrm{N}$ uptake capability and higher stress as suggested by their increased photo-respiratory activity and their lower photosynthesis. On the other hand, $\mathrm{CaSiO}_{3}$ increased tolerance to both $\mathrm{Zn}$ deficiency and toxicity because contributed to maintained plant growth. This could be related to $\mathrm{CaSiO}_{3}$ enhanced $\mathrm{Zn}$ accumulation in $\mathrm{Zn}$-deficient plants and reduced $\mathrm{Zn}$ accumulation in $\mathrm{Zn}$-toxicity plants. Likewise, $\mathrm{CaSiO}_{3}$ increased $\mathrm{N}$ uptake capacity, $\mathrm{NH}_{4}{ }^{+}$assimilation by GDH and AAT activities, and $\mathrm{N}$ reduction under $\mathrm{Zn}$ deficiency. In addition, results suggest lower stress as plants presented lower photorespiration and AAs concentration, higher pigments concentration, and better photosynthesis performance. Briefly, the results suggest that $\mathrm{CaSiO}_{3}$ increases tolerance of plants to both low and high $\mathrm{Zn}$ doses, although further research is required to reveal its mechanism of action.

Author contribution statement JMR, BB, and SE conceived the idea and designed the experiment. VP, and ENL performed the experiment. VP, and ENL analyzed the data. VP, and ENL wrote the manuscript. JMR, BB, and SE revised the manuscript. All authors read and approved the final draft.

Supplementary Information The online version contains supplementary material available at https://doi.org/10.1007/s11738-021-03325-y.

Acknowledgements This work was supported by the PAI programme (Plan Andaluz de Investigación, Grupo de Investigación AGR282). V.P. Acknowledges Erasmus traineeship program by the University of Naples "Federico II". The results presented in this paper are based on the $\mathrm{PhD}$ Thesis by Paradisone (2018).

Funding Funding for open access charge: Universidad de Granada / CBUA.

\section{Declarations}

Conflict of interest The authors declare that they have no conflict of interest.
Open Access This article is licensed under a Creative Commons Attribution 4.0 International License, which permits use, sharing, adaptation, distribution and reproduction in any medium or format, as long as you give appropriate credit to the original author(s) and the source, provide a link to the Creative Commons licence, and indicate if changes were made. The images or other third party material in this article are included in the article's Creative Commons licence, unless indicated otherwise in a credit line to the material. If material is not included in the article's Creative Commons licence and your intended use is not permitted by statutory regulation or exceeds the permitted use, you will need to obtain permission directly from the copyright holder. To view a copy of this licence, visit http://creativecommons.org/licenses/by/4.0/.

\section{References}

Adrees M, Ali S, Rizwan M, Zia-ur-Rehman M, Ibrahim M, Abbas F, Farid M, Qayyum MF, Irshad MK (2015) Mechanisms of siliconmediated alleviation of heavy metal toxicity in plants: a review. Ecotox Environ Safe 119:186-197

Anitha A, Mary P, Thiruvarassan S (2019) Alleviation of osmotic stress effects by exogenous application of silicon nutrient on sugarcane seedlings. Res Crop 20(2):419-429

Anwaar SA, Ali S, Ali S, Ishaque W, Farid M, Farooq MA, Najeeb U, Abbas F, Sharif M (2015) Silicon (Si) Alleviates Cotton (Gossypium Hirsutum L.) from Zinc (Zn) toxicity stress by limiting Zn uptake and oxidative damage. Environ Sci Pollut R 22(5):3441-3450

Ashraf M, Foolad MR (2007) Roles of glycine betaine and proline in improving plant abiotic stress resistance. Environ Exp Bot 59:206-216

Atilio B, Causin HF (1996) The central role of amino acids on nitrogen utilization and plant growth. J Plant Physiol 149(3-4):358-362

Bradford MM (1976) A rapid and sensitive method for the quantitation of microgram quantities of protein utilizing the principle of protein-dye binding. Anal Biochem 72:248-254

Broadley MR, White PJ, Hammond JP, Zelko I, Lux A (2007) Zinc in plants. New Phytol 173:677-702

Brown PH, Cakmak I, Zhang Q (1993) Form and function of Zinc plants. In: Robson AD (ed) Zinc in soils and plants. Springer, Netherlands, Dordrecht, pp 93-106

Cataldo DA, Maroon M, Schrader LE, Youngs VL (1975) Rapid colorimetric determination of nitrate in plant tissue by nitration of salicylic acid. Commun Soil Sci Plant Anal 6:71-80

Das S, Green A (2013) Importance of zinc in crop and human health. J SAT Agric Res 11:1-7

De la Torre F, Cañas RA, Pascual MB, Avila C, Cánovas FM (2014) Plastidic aspartate aminotransferases and the biosynthesis of essential amino acids in plants. J Exp Bot 65(19):5527-5534

Epstein E (2009) Silicon: its manifold roles in plants. Ann Appl Biol 155:155-160

Erenoglu EB, Kutman UB, Ceylan Y, Yildiz B, Cakmak I (2011) Improved nitrogen nutrition enhances root uptake, root-to-shoot translocation and remobilization of zinc $(\mathrm{Zn})$ in wheat. New Phytol 189:438-448

Esposito S (2016) Nitrogen assimilation, abiotic stress and glucose 6-phosphate dehydrogenase: the full circle of reductants. Plants $5(2): 24$

Feierabend J, Beevers H (1972) Developmental studies on microbodies in wheat leaves. Planta 123:63-77

Gisbert C, Clemente R, Navarro-Aviñó J, Baixauli C, Ginér A, Serrano R, Walker DJ, Bernal MP (2006) Tolerance and accumulation of heavy metals by Brassicaceae species grown in contaminated soils from Mediterranean regions of Spain. Environ Exp Bot 56(1):19-27 
Gong B, Wen D, Vanden Langenberg K, Wei M, Yang F, Shi Q, Wang $\mathrm{X}$ (2013) Comparative effects of $\mathrm{NaCl}$ and $\mathrm{NaHCO}_{3}$ stress on photosynthetic parameters, nutrient metabolism, and the antioxidant system in tomato leaves. Sci Hortic 8157:1-12

Gonzalez EM, Gordon AJ, James CL, Arrese-Igor C (1995) The role of sucrose synthase in the response of soybean nodules to drought. J Exp Bot 26:1515-1523

Grieve CM, Grattan SR (1983) Rapid assay for determination of water soluble quaternary ammonium compounds. Plant Soil 70:303-307

Groat RG, Vance CP (1981) Root nodule enzymes of ammonia assimilation in alfalfa (Medicago sativa L.): Developmental Patterns and response to applied nitrogen. Plant Physiol 67:1198-1203

Guerriero G, Hausman JF, Legay S (2016) Silicon and the plant extracellular matrix. Front Plant Sci 7:463

Hajiboland R, Amirazad F (2010) Drought tolerance in Zn-deficient red cabbage (Brassica oleracea $\mathrm{L}$. var. capitata f. rubra) plants. Hort Sci (prague) 37:88-98

Havaux M (1998) Carotenoids as membrane stabilizers in chloroplasts. Trends Plant Sci 3:147-151

He C, Wang L, Liu J, Liu X, Li X, Ma J, Lin Y (2013) Evidence for 'silicon' within the cell walls of suspension-cultured rice cells. New Phytol 200:700-709

Hernández-Apaolaza L (2014) Can silicon partially alleviate micronutrient deficiency in plants? A review. Planta 240:447-458

Holländer-Czytko H, Grabowski J, Sandorf I, Weckermann K, Weiler EW (2005) Tocopherol content and activities of tyrosine aminotransferase and cystine lyase in Arabidopsis under stress conditions. J Plant Physiol 162(7):767-770

Höller S, Hajirezaei MR, Wirén N, Frei M (2013) Ascorbate metabolism in rice genotypes differing in zinc efficiency. Planta 239:367-379

Igarashi D, Tsuchida H, Miyao M, Ohsumi C (2006) Glutamate:glyoxylate aminotransferase modulates amino acid content during photorespiration. Plant Physiol 142:901-910

Kabir AH, Swaraz AM, Stangoulis J (2014) Zinc-deficiency resistance and biofortification in plants. J Plant Nutr Soil Sc 177(3):311-319

Kaiser JJ, Lewis OAM (1984) Nitrate reductase and glutamine synthetase activity in leaves and roots of nitrate-fed Helianthus annuus L. Plant Soil 77:127-130

Krom MD (1980) Spectrophotometric determination of ammonia: a study of a modified Berthelot reaction using salicylate and dichloroisocyanurate. Analyst 105:305-316

Luna CM, Casano LM, Trippi VS (2000) Inhibition of wheat nitrate reductase activity by zinc. Biol Plant 43:257-262

Murillo-Amador B, Yamada S, Yamaguchi T, Rueda-Puente E, Ávila-Serrano N, García-Hernández JL, López-Aguilar R, Troyo-Diéguez E, Nieto-Garibay A (2007) Influence of calcium silicate on growth, physiological parameters and mineral nutrition in two legume species under salt stress. J Agron Crop Sci 193(6):413-421

Navarro-León E, Barrameda-Medina Y, Lentini M, Esposito S, Ruiz JM, Blasco B (2016) Comparative study of $\mathrm{Zn}$ deficiency in $L$. sativa and $B$. oleracea plants: $\mathrm{NH}_{4}{ }^{+}$assimilation and nitrogen derived protective compounds. Plant Sci 248:8-16

Navarro-León E, Ruiz JM, Albacete A, Blasco B (2019) Effect of CAX1a TILLING mutations and calcium concentration on some primary metabolism processes in Brassica rapa plants. J Plant Physiol 237:51-60

Nicolle C, Carnat A, Fraisse D, Lamaison JL, Rock E, Michel H, Amouroux P, Remesy C (2004) Characterisation and variation of antioxidant micronutrients in lettuce (Lactuca sativa folium). J Sci Food Agric 84(15):2061-2069

Paradisone V, Barrameda-Medina Y, Montesinos-Pereira D, Romero L, Esposito S, Ruiz JM (2015) Roles of some nitrogenous compounds protectors in the resistance to zinc toxicity in plants. Acta Physiol Plant 37:1-8

Paradisone V (2018) Zinc limitation and toxicity in crops and effects of Silicon in ameliorating stress response. PhD Thesis, Università degli Studi di Napoli Federico II, Napoli, Italy

Pascual MB, Echevarria V, Gonzalo MJ, Hernández-Apaolaza L (2016) Silicon addition to soybean (Glycine max L.) plants alleviate zinc deficiency. Plant Physiol Bioch 108:132-138

Pfannschmidt T, Yang C (2012) The hidden function of photosynthesis: a sensing system for environmental conditions that regulates plant acclimation responses. Protoplasma 249(S2):125-136

Prasad R, Shivay YS, Kumar D (2016) Interactions of zinc with other nutrients in soils and plants-a review. Indian J Agr Sci 12(5):16-26

Rao B, Gao L, Dai H, Hong Z, Xie H (2019) An efficient and sustainable approach for preparing silicon fertilizer by using crystalline silica from ore. JOM 71(11):3915-3922

Rizwan M, Ali S, Ibrahim M, Farid M, Adrees M, Bharwana SA, Zia-ur-Rehman M, Qayyum MF, Abbas F (2015) Mechanisms of silicon-mediated alleviation of drought and salt stress in plants: a review. Environ Sci Pollut R 22(20):15416-15431

Robinson SA, Slade AP, Fox GG, Phillips R, Ratcliffe RG, Stewart GR (1991) The role of glutamate dehydrogenase in plant nitrogen metabolism. Plant Physiol 95:509-516

Seethambaram Y, Das VSR (1986) Effect of zinc deficiency on enzyme activities of nitrate reduction and ammonia assimilation of Oryza sativa L. and Pennisetum americanum L. Leeke. Proc Indian Natl Sci Acad 4:491-496

Singh RP, Srivastava HS (1986) Increase in glutamate synthase $(\mathrm{NADH})$ activity in maize seedlings in response to nitrate and ammonium nitrogen. Physiol Plant 66:413-416

Sivanesan I, Son MS, Lim CS, Jeong BR (2011) Effect of soaking of seeds in potassium silicate and uniconazole on germination and seedling growth of tomato cultivars, Seogeon and Seokwang. Afr J Biotechnol 10:6743-6749

Smirnnoff N, Stewart GR (1987) Nitrogen assimilation and zinc toxicity to zinc-tolerant and non-tolerant clones of Deschampsia cespitosa (L.) beauv. New Phytol 107:671-680

Song JY, Jeong BR (2014) Effect of silicate source on growth of the Lsi2 transgenic plants of chrysanthemum 'Brighton.' Hortic Environ Biotechnol 55(5):428-436

Song A, Li P, Fan F, Li Z, Liang Y (2014) The effect of silicon on photosynthesis and expression of its relevant genes in rice (Oryza sativa L.) under high-zinc stress. PLoS ONE 9(11):e113782

Strasser RJ, Tsimilli-Michael M, Srivastava A (2004) Analysis of the chlorophyll a fluorescence transient. In chlorophyll a fluorescence. Springer, Netherlands, Dordrecht, pp 321-362

Wellburn AR (1994) The spectral determination of chlorophylls a and $\mathrm{b}$, as well as, total carotenoids, using various solvents with spectrophotometers of different revolution. J Plant Physiol 144:307-313

White PJ, Broadley MR (2003) Calcium in plants. Ann Bot 92(4):487-511

Wingler A, Lea PJ, Quick WP, Leegood RC (2000) Photorespiration: metabolic pathways and their role in stress protection. Philos Trans R Soc Lond B Sci 355:1517-1529

Wolf B (1982) A comprehensive system of leaf analyses and its use for diagnosing crop nutrient status. Commun Soil Sci Plant Anal 13:1035-1059

Zhao K, Wu Y (2017) Effects of Zn deficiency and bicarbonate on the growth and photosynthetic characteristics of four plant species. PLoS ONE 12(1):e0169812 (Edited by Maoteng Li)

Publisher's Note Springer Nature remains neutral with regard to jurisdictional claims in published maps and institutional affiliations. 